Research Article

\title{
Role of a Consultancy Partner in Microfinancing
}

\author{
Munehsia Maheswari, Marium Mateen Khan and Aamir Firoz Shamsi \\ Institute of Business Management, Karachi, Pakistan
}

Correspondence should be addressed to: Marium Mateen Khan; marium.mateen@iobm.edu.pk

Received date: 13 February 2017; Accepted date: 16 May 2017; Published date: 4 September 2017

Academic Editor: Norli Ali

Copyright (C) 2017. Munehsia Maheswari, Marium Mateen Khan and Aamir Firoz Shamsi . Distributed under Creative Commons CC-BY 4.0

\begin{abstract}
This research aims at identifying the approaches used by microfinance banks in managing credit risk. Furthermore, it aims at examining the applicability of introducing the element of consultancy (consultant) in the equation to reduce credit risk. Primary data were used, which were collected through structured closed-ended questionnaires and semi-structured interviews. Purposive sampling was used to select credit officer and loan officer from each of the sampled bank. 6 Interviews were also conducted from manager and higher level management regarding the applicability of consultancy concept. The analysis of the data revealed that, $85.7 \%$ respondents agree that they use five Cs' of credit risk to analyze the borrower situation before lending loan to them, while $76.2 \%$ respondents agreed that the microfinance banks are harmed when borrowers fail to repay loans because of over indebtedness, poor client understanding, and other such issues. The acceptability of consultancy concept was asked through interviews, researchers received mixed responses. 2 out of 6 interviewees were not in favor of consultancy concept. One interviewee favored the introduction of a consultant in the area of microfinancing, while commenting he said that this concept is prevalent in the developed countries and can be used in Pakistan but its acceptability will require at least 5 years to get established in Pakistan.
\end{abstract}

Keywords: Microfinancing, credit risk, micro to mini financing, facilitation, consultant, consultancy, stakeholder, 5 Cs

\section{Introduction}

Microfinance or microcredit is attributed by Otero, (1999) to be "the provision of financial services to low income poor and very poor self-employed people". Microfinance is generally associated with the low income segments of the society and is characterized as supplying loans, savings and other related financial services like insurance to poor

Cite this Article as: Munehsia Maheswari, Marium Mateen Khan and Aamir Firoz Shamsi (2017)," Role of a Consultancy Partner in Microfinancing", Journal of Southeast Asian Research, Vol. 2017 (2017), Article ID 560941, DOI: $10.5171 / 2017.560941$ 
segments. These segments have lesser access to credit and other financial facilities under conventional banking setup. Under recent global consensus, it is agreed that Microfinance institutions (MFIs) fill the gap of conventional banks' limitations in reaching the poor and provides them with banking services. They function as banks for poor people by providing them with services that are available for upper-income population through banks. MFIs help low income people to expand their businesses by enabling them to gain access to micro-finance services. Those service include: credit, savings, and micro-insurance, which pull them out of poverty.

\section{The Emergence of Microfinance}

Decreasing poverty and improving the lifestyle of poor segments of the society is a challenge. Improving the lives of poor people requires efforts from each sector of the economy and cannot just be achieved via economic growth. With better approach to financial services, poor people can make payment transactions which can be brought into the formal sector. Financial services provide an opportunity to poor people to take advantage of business opportunities that can bring profit and increase earnings. With inadequate traditional forms of collateral to offer, poor people are usually excluded from financial markets. The formal financial institutions would not outspread credit services to the poor people because of the uncertainty that loans would not be repaid. Moreover, loans taken by poor people from formal financial institutions were also subjected to high transaction costs, such as time, travel and paperwork in attaining credit. In the rural areas of many developing countries governments and international aid donors have been providing subsidized credit to small farmers since 1950's. Poor people faced a lot of trouble in obtaining lowinterest credit by the monopolistic money lenders. Development finance institutions were responsible for providing low-interest credit to poor farmers. These institutions monitored the use of the loans that were provided and set the repayment schedules which were based on the expected income flow from the investment returns. The returns were often overestimated which resulted in loans not being repaid. The development finance institutions were unable to sustain these lending programs because of the poor investment decisions and low repayment rates by the poor people. Donors and other resource providers critiqued the model of subsidized credit. They commend that the model should move to market based solutions instead of government intervention subsidy. Policy makers were reminded that credit should be defined as debt and that the over-supply of subsidized credit without careful valuation of people's capacity to repay could result in failure for borrowers (Tiruneh, 2006). Poverty lending approach and financial system approach are two common approaches in microfinance development (Robinson, 2001). The main aim of both approaches is to make financial services available to poor people all over the world.

Grameen Bank in Bangladesh first discovered the poverty lending approach. This approach has an extensive outreach to poor people. But this method needs huge amount of enduring subsidies and poor people's demand does not meet for saving services and therefore, it has not recognized a worldwide affordable model (Robinson, 2001). The credit organizations have failed to address the basic financial needs of the poor segments of the society and therefore, the situation required an innovative approach to address the issues that were not addressed by the poverty lending approach. The shortcomings of the old approach should be corrected by this new approach (Hailu, 2005). This new approach is called the financial system approach. The financial system method emphasizes commercial financial intermediation among poor borrowers and savers; and furthermore emphasizes institutional self-sufficiency. This approach provides credit to poor people who are economically active i.e. people with the

Munehsia Maheswari, Marium Mateen Khan and Aamir Firoz Shamsi (2017), Journal of Southeast Asian Research, DOI: 10.5171/2017.560941 
capability to appropriately utilize loans and the willingness to repay.

The domain of microfinance has developed more covering a wider range of products and services, including credits and savings, insurance and money transfers. Microfinance is the process of providing financial services to those who are not taken into consideration in the formal financial system (SUM, 2002). According to Parker, (2000) microfinance is the provision of financial services which include: credits, savings, insurance and other services to clients who lack access to these services in the formal financial institutions on viable basis.

\section{Credit Risk}

When debtors are not able to repay their loans, credit risk arises. This results in a loss of revenue for MFPs. Since most of the lending is not secured as traditional forms of collateral are not used, credit risk is an important issue of concern for MFPs. Generally, credit risk seems as one of the utmost threats to microfinance, owing to client over-indebtedness, competition, pricing, staffing difficulties, weak internal controls and irresponsible lending practices administered by MFPs. Pakistan also has similar issues but competition and weak lending standards are the main contributors to credit risk. Growth in outreach has closely followed existing high-density areas, leading these regions to become more and more saturated. Because of competition, MFPs have a higher probability to compromise on lending standards which leads to multiple borrowing and over-indebtedness. In addition to this, lack of coherent risk management structures and strong credit risk appraisal mechanisms make MFPs more vulnerable to this risk. According to a consultant from the microfinance sector, non-bank MFPs have the highest credit risk because the methods used by them for credit appraisal are inappropriate having weak institutionalizations. Due to weak lending practices, a large number of respondents have raised concerns regarding the misuse of microfinance loan. A non-bank practitioner has stated that "loans provided for income generating activities (such as for agriculture or trade) are often consumed on personal requirements or to repay existing debts". Another practitioner noted that "the nonproductive use of microloans is a key determinant of over-indebtedness". The moderation of credit risk requests an upgrade of credit risk management practices. Likely methods could be such as, employing significance human resources and reviewing incentive systems, executing an inclusive 'know-your-customer' philosophy, mounting due diligence procedures with constant applications, reconsidering loan sizes, systematizing the use of the Microfinance Credit Information Bureau (MF-CIB) and concentrating on building long term relationships. MFPs should advance strong risk exposure plans within each sector they operate in and for each product and limit the part of their portfolios subjected to risk from one sector/product, thus, keeping a healthy risk-versus-growth balance (Arshad, 2015)

\section{Management of Micro Finance}

The management of micro finance is challenging on the grounds that it has dual objective to achieve through its services and functions: the financial stability on one side and the social influence on the other side. The functions of human resource, marketing, corporate environment are influenced by these objectives in relation to their policies for the management of risks, transactions and costs as well.

\section{Present Micro Financing Structure}

In the present structure of Micro financing, whenever any micro financing is needed by the borrower, he/she approaches to one of the Micro Financing Banks and asks for the specified amount along with the description of the business he/she wants to do or in some cases wanted to expand the existing business. In response the bank asks the customer about their business and lends money to him/her after taking some 
guarantee as cover in case of default. The money borrowed by customer is on interest based. Interest rate charged by the bank to the customer is set by the bank itself. So the customer is bound to pay the specified interest payments periodically otherwise he/she will be marked as defaulter and guarantor will be liable for it.

\section{Debt Efficiency Management Model (DEM) as Modified Micro financing Structure}

In proposed and modified Micro Financing Structure that is Debt Efficiency Management Model (DEM) is to provide a gateway through which effective management of micro financing can be possible at both lender and borrower ends. The vision behind the DEM is to introduce a third person as a Proxy Consultant (PC) among lender and borrower that will provide consultancy to the borrower to invest in prosperous projects. Proxy consultant (PC) will act as an entrepreneur for the borrower.

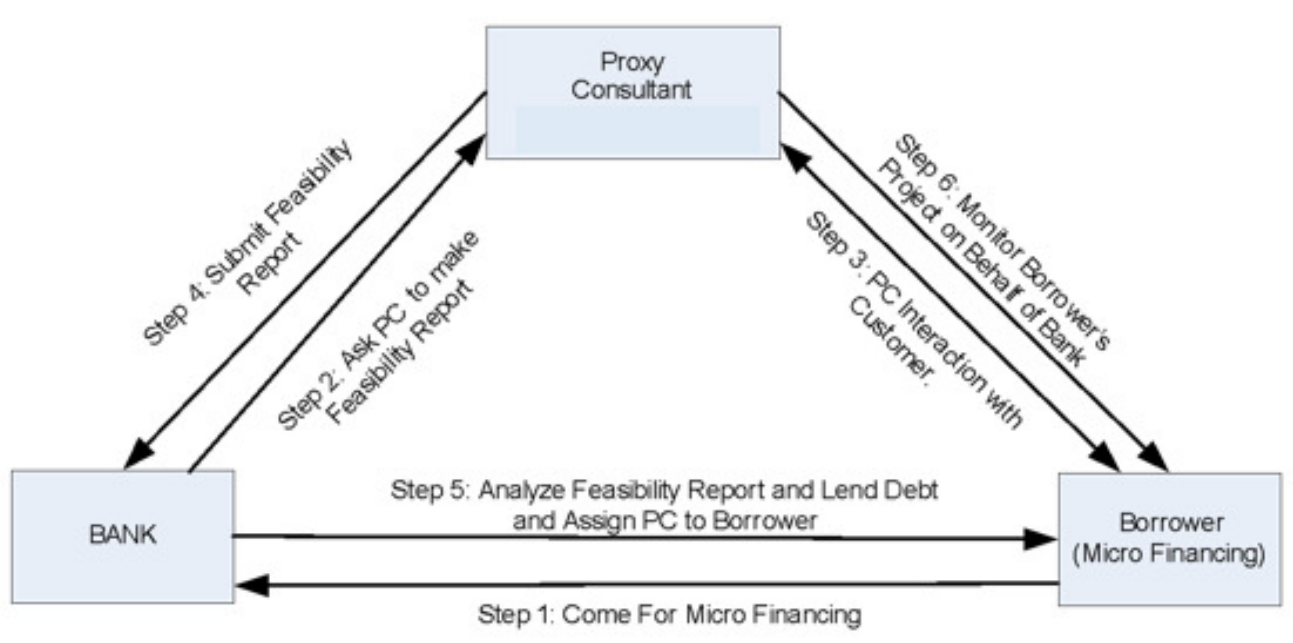

\section{Objective}

To learn and understand the applicability of the specified model of microfinance institution, consultancy and borrower linkage/partnership in the light of credit risk. Scope

The scope of this research is to provide a better and prosperous micro financing structure for the customers. So that it can work as part of reducing poverty in the country, because when the borrower investment flourishes, their standard of living increases. Secondly, unemployment is one of the major economic problems of our country, this way Proxy Consultant gets jobs in case of DEM as modified micro financing structure. Thirdly rate of return will increase and banks' confidence towards lending increases and eventually they will offer more loan packages.

\section{Gap}

In the emerging markets access to capital for entrepreneurs has become easier, however significant challenges are still present for them (Yoshikawa et al., 2006). According to Yiu et al., (2005) accessibility to credible and reliable information about the borrowers present one of the biggest challenges for the lenders. Furthermore, due to the lack of appropriate information available to the lenders, they will have to make uncertain decisions regarding investment. Asymmetry in available information also decreases the lenders' willingness to provide capital to entrepreneurs.

Munehsia Maheswari, Marium Mateen Khan and Aamir Firoz Shamsi (2017), Journal of Southeast Asian Research, DOI: 10.5171/2017. 560941 
In the past it was believed that only finance was important for a business enterprise to start its processes and grow, however (Sievers and Vandenberg, 2007), suggest that credit is not enough to ensure the sustainability of an enterprise. Enterprises need business development services that bridge the gap between the lenders and borrowers. Business development service providers (consultants) not only bring the two parties together but also provide both of them with customized services as per their needs. For successful collaboration amongst the three entities require linkages that benefit all three actors involved; the enterprises, microfinance institutions and the consultant (business development service provider also known as the BDS provider).

\section{Problem Statement}

In Pakistan the microfinance institutions themselves play the dual role of credit providers and consultants, which results in bias decisions at times. While creating a threefold responsibility on then lenders to monitor, consult and provide credit to the borrowers. In some cases the enterprises themselves play the role of consultant, even though they may lack budgeting and other required expertise or outsource an institution for budget consultation. In both cases, whether the microfinance institution plays the role of a consultant or the borrower steps in that role, the chances of biasness and failure increase. Hence, having a successful linkage between the two parties comes under risk. Furthermore, the element of credit risk also arises here and creates chances of several loan defaults.

\section{Justification}

This research aims at creating and providing a conceptual frame work and model to lessen the burden of the lenders and borrowers by introducing a third middle entity to link the lenders and borrowers with each other, also, to reduce their burden of monitoring and consultation. The model under concern will monitor and provide the required information about the borrower to the lenders to make their investment decision. After the decision is made in favor of the borrower, the consultant will step into the role of a mentor and provide the borrowing enterprise with the guidance and training to develop required skills to make the venture successful. At the same time, the consultant will lend a hand to the lenders by playing the role of a monitoring entity on the microfinance institution's behalf.

\section{Literature Review}

\section{Borrower Characteristics}

In a study conducted by Moss et al., (2015), they found that enterprises that exhibit characteristics that include: risk taking, autonomy and competitive aggressiveness are more likely and more quickly to receive funding from the lenders. On the other hand the enterprises that exhibit empathy, courage, warmth and conscientiousness are less likely to get funded. Furthermore, it was found that there was a negative association between loan repayment and rhetorical signals that include: conscientiousness, courage, zeal, warmth and proactiveness.

\section{Credit Risk aspect of Micro-financing}

Credit risk has become the focal point in micro-financing due to the huge losses suffered by several big financial organizations internationally (Nikolaidou and Vogiazas, 2014). To ward off future chances of any such events the financial institutions have taken measures to ensure no losses are incurred in the future. The majority of the institutions providing financial loans to individuals are banks and the losses of the past have shed some light on the areas that create credit risk. Few of those areas include mismanagement in the loan allocations and recoveries of credit from the borrowers. The solution that the financial institutions have commonly agreed on is the management of credit risk. Presently credit risk management is considered a comprehensive and viable approach to 
reduce the element of risk in financial institutions like the banking sector (Arora and Kumar, 2014).

According to Nkusu, (2011) for a viable management of credit risk the key point is to judiciously oversee the client to whom the loan has been given. Furthermore, to minimize the intervention of over-saving, terrible obligations and liquidations banks require to get themselves properly familiar with the client's history, financial assessment, budgetary quality and change in installment design to facilitate the repayment of loan by the client.

Credit risk management continues till the last installment of the loan has been paid by the client. Therefore, when the financial condition of the client changes the banks and financial institutions should also change their approach for credit (Moti et al., 2012). Several research studies have been conducted to analyze the aspects of credit risk but rarely this issue has been covered with respect to Pakistani context (Ahmed and Malik, 2015).

\section{Consultancy}

Consultancy from a third party means that the new venture can acquire a distinctive mix of explicit and tactic knowledge. Chrisman and McMullan (2004), through a longitudinal study of four to eight years of consultation provision, concluded that the counselling to the venture showed excess survival rate in comparison to other ventures found in general population. Moreover, analysis through logistic regression showed a positive relationship between the survival of a new venture and the time spent under the guidance, training and direction of an outside (third party) counsellor.

A mentor is an individual that provides guidance, support, expertise, motivation and helps in developing skills and knowledge of the mentee through his own experiences and knowledge (Cuerrier, 2004). The concept of mentorship has become a part of various fields including organizational education (Tedder and Lawy, 2009), youth and community (Monaghan and Lunt, 1992) and now in entrepreneurship (El Hallam and StJean, 2016).

Researchers have found the mentoring provided to an entrepreneur has a positive impact on the entrepreneurs learning, knowledge, success and business survival rate (El Hallam and St-Jean, 2016). Keeping in mind the value of independence for the entrepreneurs, mentoring is seen as an effective alternative for traditional forms of training (Moreland and Clark, 1992). Studies show that in terms of cognitive learning, mentoring helps entrepreneurs in identifying new and better business opportunities (Ozgen and Baron, 2007). Mentoring also increases the entrepreneurs' knowledge about financial, managerial and marketing aspects of business through the insights provided by the mentors (Simard and Fortin, 2008). Other studies revealed that for effective learning and through building up of skills mentoring creates a sense of self efficacy (Barnir, 2014), confidence on one's own abilities (Cull, 2006) and creates perseverance in the entrepreneur to overcome difficult situations (El Hallam and St-Jean, 2016).

Sullivan, (2000) states that mentoring is a unique opportunity for the entrepreneurs as it provides just in time and customized training to the intended audience. Hence it is cost effective in the long run than a traditional training approach. According (Gartner et al., 1999) to an entrepreneur's learning is directly proportional to the survival and success of a venture in its first year. However, the significance of mentoring in business performance is difficult to establish in its initial years as some benefits are only observed in later years. During the time from initiation of the venture till later years other factors may arise including change in market dynamics, policies, laws and economic conjectures. Nonetheless, the

Munehsia Maheswari, Marium Mateen Khan and Aamir Firoz Shamsi (2017), Journal of Southeast Asian Research, DOI: 10.5171/2017. 560941 
key point is the impact consultancy or mentorship has on the learning, increase in knowledge and decision making of the mentee which obviously gets influenced by the mentor. Previously the role of the consultant was mainly absent, and if it were present, it only monitored the borrower. But in the model presented by the researchers the consultant plays the role of a mentor as well as the role of a stakeholder, who would work for both parties (the lender and the borrower). Furthermore, the consultant being the stakeholder in the contract will strive for the successful repayment of the loan and growth of the borrower's business.

\section{Methodology}

\section{Research Design}

Descriptive research design was used in this study. A descriptive study was concerned with finding out who, what, where and how of a phenomenon (Cooper \& Martin, 1996). A handy approach to determine the authenticity of qualitative research was triangulation since having both a qualitative and a quantitative method allowed the researcher to potentially complement each method's weaknesses with other method's strength. This design has been successfully used by Njoroge (2003) in the past. The specific design used analyzed the impact of credit risk on the performance of microfinance banks and furthermore, the applicability of introducing the element of consultancy (consultant) in the equation to reduce credit risk, facilitate the microfinance banks in overlooking the borrowers, monitor their progress and also to mentor the borrowers and improve their skills for future growth.

\section{Population}

The population of interest in this study was all the loan and credit officers of microfinance banks operating in Karachi Pakistan. There are 10 Microfinance banks in Karachi Pakistan according to the State bank of Pakistan (2015).

\section{Sample Selection and Sample Size}

A non-probability sampling technique was used and 8 Micro-Finance banks were taken from the population. This constitutes $80 \%$ of the entire population. The method used to select credit and loan officers from the sampled bank was purposive sampling. The researchers used Raosoft to deduce the sample size from the population which came out to be of 21 respondents who were sampled to participate in the study and asked about credit risk present in microfinance banks. 6 Interviews were also conducted from manager and higher level management regarding the applicability of consultancy concept. The interviews provided an idea about the degree of acceptability of the consultancy element in the Microfinancing equation.

\section{Data Collection Methods}

Primary data were used in this study, which were collected by way of structured closedended questionnaires and semi-structured interviews. The focus of the questionnaire was recognized on the techniques used by Micro- Finance banks in the management of credit risk. While, the Interviews were conducted to analyze and reinforce the degree of acceptability of the consultancy concept being used by the microfinance banks so far. The questionnaires were selfadministered. The interviews were conducted at the same time from manager and higher level management available at the respective banks.

\section{Data Analysis}

The data were analyzed using descriptive statistics (means and standard deviation) to measure the credit risk variables. Interviews were conducted while the questionnaires were being filled by the credit and loan officers. The interviews provided insights to the researchers regarding the credit risk, monitoring of borrowers, number of defaulters, training to the staff, and the 
acceptability of consultant in mentoring and monitoring of borrowers as stakeholders.

Table 1 : Data Analysis and Findings

\begin{tabular}{|c|c|c|c|c|c|c|c|c|}
\hline \multicolumn{9}{|c|}{ Descriptive Statistics } \\
\hline \multirow[t]{2}{*}{ Factors } & \multirow{2}{*}{ Mean } & \multirow{2}{*}{$\begin{array}{c}\text { Std. } \\
\text { Deviation }\end{array}$} & \multicolumn{3}{|c|}{ Frequency } & \multicolumn{3}{|c|}{ Percent } \\
\hline & & & Agree & Neutral & Disagree & Agree & Neutral & Disagree \\
\hline Repayment of Loan & 4.10 & 0.768 & 16 & 5 & - & 76.2 & 23.8 & - \\
\hline Use of five Cs & 4.38 & 0.740 & 18 & 3 & - & 85.7 & 14.3 & - \\
\hline $\begin{array}{l}\text { Dishonest } \\
\text { Customer }\end{array}$ & 3.57 & 0.978 & 12 & 7 & 2 & 57.2 & 33.3 & 9.6 \\
\hline Dishonest Staff & 3.24 & 1.338 & 8 & 8 & 5 & 38.1 & 38.1 & 23.8 \\
\hline $\begin{array}{l}\text { Inappropriate } \\
\text { Regulation }\end{array}$ & 3.38 & 1.359 & 10 & 5 & 6 & 47.6 & 23.8 & 28.5 \\
\hline $\begin{array}{l}\text { Fluctuation in } \\
\text { Interest rate }\end{array}$ & 2.86 & 1.108 & 5 & 5 & 11 & 23.8 & 23.8 & 52.4 \\
\hline $\begin{array}{l}\text { Challenge for } \\
\text { Growth }\end{array}$ & 3.81 & 0.814 & 14 & 6 & 1 & 66.6 & 28.6 & 4.8 \\
\hline Technology & 3.95 & 0.865 & 15 & 5 & 1 & 71.5 & 23.8 & 4.8 \\
\hline Profitability & 3.48 & 1.250 & 13 & 3 & 5 & 61.9 & 14.3 & 23.8 \\
\hline Human resources & 2.71 & 1.419 & 7 & 3 & 11 & 33.3 & 14.3 & 76.2 \\
\hline Survival & 4.00 & 1.095 & 16 & 3 & 2 & 76.2 & 14.3 & 9.6 \\
\hline
\end{tabular}

\section{Interpretations}

Respondents were asked to what extent the banks have been using the credit risk factors listed in Table-1. 85.7\% respondents agreed that their microfinance banks use five C's of credit risk to analyze the borrower's situation before giving a loan to the borrowers. Which implies that the lenders are conscious when lending and they follow the conventional process prescribed by finance policy makers to analyze the borrower's situation. $76.2 \%$ respondents agreed that the growth of microfinance banksgets damaged when borrowers fail to repay loans. Failure to repay loans can be due to several reasons which includes: but is not limited to the client's poor understanding of repayment policies, limited skills of the client, lack of business growth, etc. 57.2\% respondents agreed that microfinance banks get damaged due to the dishonest customers. The other factors such as inappropriate regulations, innovative technology, profitability, new strategies to survive, respondents gave a higher percentage that they are affected in microfinance banks due to the earlier mentioned factors.

\section{Interviews}

All the participants expressed their views regarding consultancy concept. 2 out of 6 participants were not in favor of consultancy concept, they said this practice was already being used in microfinance banks and it has not proved helpful. Another participant responded that consultancy concept is being

Munehsia Maheswari, Marium Mateen Khan and Aamir Firoz Shamsi (2017), Journal of Southeast Asian Research, DOI: 10.5171/2017.560941 
employed in developed countries and it will be workable in Pakistan however, it will take 5 years more to be established and become acceptable here. The respondent from one of the microfinance banks expressed his views by stating that consultancy is a really beneficial concept, as microfinance lending is for poor people: they are not educated, they do not know how to utilize loan properly. According to him monitoring is done in microfinance banks but mentoring is not in practice. The borrowers are observed to mostly utilize the loan for other purposes than the real purpose that was mentioned in their application for loan. He even encouraged the researchers to write a note to the State bank to work on the concept of consultancy as a stakeholder with the lender and borrower in this scenario.

The other two participants indicate that instead of consultancy concept, bank higher management level people should educate the current staff of microfinance bank to familiarize them with the monitoring and mentoring of the customers, in short to educate the customers about the overall loan process, repayment and growth of their own respective businesses. The banks should provide incentives like bonuses, trips etc. to the staff to encourage them and reduce the number of bad loans, fast repayment of loan and proper utilization of loan amount by the borrowers while working towards the basic function of microfinance i.e. Poverty reduction will be achieved.

\section{Discussion}

In past studies the credit risk aspect was already researched however, in this study the researchers have introduced the element of consultant playing a multirole of a monitor, mentor and a stakeholder while being a liaison between the lender and the borrowers. The element introduced was justified by the interviews conducted by the researchers through which it was deduced that even after using the traditional practices of microfinance including the usage of $5 \mathrm{Cs}$, even then the credit risk and default rate were observed to be high. Therefore, by introducing the consultant in the present equation it is expected that the repayment of loans will be at a faster and at an effective rate along with the growth of the borrower's business.

\section{Conclusion and Recommendation}

Based on the analysis of the data collected from the survey and the interviews, the following conclusions are drawn: First, most microfinance banks (85.7\%) use five Cs of credit risk management, i.e. character, collateral, capacity, capital and conditions as a basic tool when deciding to lend money to a borrower. On the other hand, even after the use of five Cs, the microfinance banks face over-indebtedness, poor credit management, and poor client understanding just to name a few issues. Lack of growth even after the use of five Cs and self-hired agents by the microfinance banks has led the researchers to come to a conclusion that in the light of the literature available and the practices followed in the developed countries, there is a dire need of introducing the element of consultant (consultancy) in the microfinancing system. A consultant will play the role of a liaison between the microfinance institution and the borrower. The consultant will perform the task of analyzing the borrower's situation on behalf of the microfinance organization while preparing a budget and a marketing plan for the borrower. The task of the consultant will not end after the loan has been provided but will be as in the framework formulated in Figue-1, the researchers have made the consultant a stakeholder in the entire cycle of microfinancing with the lender and the borrower. The consultant will monitor the progress of the borrower on behalf of the microfinance institution while mentoring the borrower and helping the borrower in developing his/her personal skill for growth of the business. Furthermore, the consultant will have a profit sharing in the business of the borrower making him/her a stakeholder and hence accountable towards the successful repayment of the loan to the 
microfinance institution, while working towards the growth and expansion of the borrower's business.

\section{References}

1. Ahmed, S.F., Malik, Q.A., 2015. Credit Risk Management and Loan Performance: Empirical Investigation of Micro Finance Banks of Pakistan. Int. J. Econ. Financ. Issues 5.

2. Arora, A., Kumar, M., 2014. Credit risk management index score for Indian banking sector: an in-depth analysis. IUP J. Bank Manag. 13, 19.

3. Barnir, A., 2014. Gender Differentials in Antecedents of Habitual Entrepreneurship: Impetus Factors and Human Capital. J. Dev. Entrep. 19, 1450001.

4. Chrisman, J.J., McMullan, W.), 2004. Outsider assistance as a knowledge resource for new venture survival. J. Small Bus. Manag. 42, 229-244.

5. Cuerrier, C., 2004. Le Mentorat et le Développement Professionnel. Ottawa: Fondation.

6. Cull, J., 2006. Mentoring young entrepreneurs: what leads to success? Int. J. Evid. Based Coach. Mentor. 4, 8-18.

7. El Hallam, H., St-Jean, É., 2016. Nurturing Entrepreneurial Learning Through Mentoring. J. Dev. Entrep. 21, 1650012.

8. Gartner, W., Starr, J., Bhat, S., 1999. Predicting New Venture Survival: An Analysis of "Anatomy of a Start-up." Cases from Inc. Magazine. J. Bus. Ventur. 14, 215-232.

9. Hailu, W., 2005. Microfinance in Developing Countries: Concept and Practices. AEMFI Addis Ababa Ethiop.

10.Monaghan, J., Lunt, N., 1992. Mentoring: Person, process, practice and problems. Br. J. Educ. Stud. 40, 248-263.
11.Moreland, N., Clark, M., 1992. Training and development for small business managers. Part One: a prologue-who are the small business managers? Vocat. Asp. Educ. $44,211-232$.

12.Moss, T.W., Neubaum, D.O., Meyskens, M., 2015. The effect of virtuous and entrepreneurial orientations on microfinance lending and repayment: A signaling theory perspective. Entrep. Theory Pract. 39, 27-52.

13.Moti, H.O., Masinde, J.S., Mugenda, N.G., Sindani, M.N., 2012. Effectiveness of credit management system on loan performance: empirical evidence from micro finance sector in Kenya. Int. J. Bus. Humanit. Technol. 2, 99108.

14. Nikolaidou, E., Vogiazas, S.D., 2014. Credit Risk Determinants for the Bulgarian Banking System. Int. Adv. Econ. Res. 20, 87-102.

15.Nkusu, M., 2011. Nonperforming loans and macrofinancial vulnerabilities in advanced economies. IMF Work. Pap. 1-27.

16.Otero, M., 1999. Bringing development back, into microfinance. J. Microfinance ESR Rev. 1, 8-19.

17.Ozgen, E., Baron, R.A., 2007. Social sources of information in opportunity recognition: Effects of mentors, industry networks, and professional forums. J. Bus. Ventur. 22, 174192.

18.Parker, J., 2000. Discussion paper: Microfinance and HIV/AIDS.

19.Robinson, M.S., 2001. The microfinance revolution: Sustainable finance for the poor. World Bank Publications.

20.Sievers, M., Vandenberg, P., 2007. Synergies through linkages: Who benefits from linking micro-finance and business development services? World Dev. 35, 13411358.

21.Simard, P., Fortin, J., 2008. Mentorat des entrepreneurs. Gestion 33, 10-17.

Munehsia Maheswari, Marium Mateen Khan and Aamir Firoz Shamsi (2017), Journal of Southeast Asian Research, DOI: 10.5171/2017.560941 
22.Sullivan, R., 2000. Entrepreneurial Learning and Mentoring. Int. J. Entrep. Behav. Res. 6, 160-175.

23.Tedder, M., Lawy, R., 2009. The pursuit of "excellence": mentoring in further education initial teacher training in England. J. Vocat. Educ. Train. 61, 413-429.

24.Tiruneh, A., 2006. Impact of micro finance on poverty reduction in Ethiopia: The case of Three Branches of SFPI. Master Thesis in AAU. Addis Ababa, Ethiopia.
25.Yiu, D., Bruton, G.D., Lu, Y., 2005. Understanding business group performance in an emerging economy: Acquiring resources and capabilities in order to prosper. J. Manag. Stud. 42, 183-206.

26.Yoshikawa, T., Rasheed, A.A., Datta, D.K., Rosenstein, J., 2006. Financial and Product Market Integration: Responses of Japanese Firms. Manag. Int. Rev. 46, 529-555. 